l 1) 加藤修三, 第 6 回高温材料技術講習会テキスト, p. 49-62 (1973).

2）加藤修三，伊賀武雄，井上弘人，皿井博美，昭和 48 年窯 協年会講演要旨集, p. 32 .

3）権相旭, 金炳扈, 石川平七, 工化, 74 [12] 2411-15(1971).
4）金炳扈, 加藤忠蔵，工化， 77 [11] 2075-80 (1974).

5）加藤修三，伊賀武雄，幡野昭五，伊沢雄一，窵協，印刷 中

(7/9/1975 受付)

論文・Paper

\title{
いぶし瓦の表面状龍におよぼす燻化条件の影響
}

\author{
田中稔・元山宗之・石間健 市・橋詰 源蔵 \\ （兵庫県立工業試験場）
}

\section{Smoking Process in Manufacture of Smoked Rooftiles}

\author{
By \\ Minoru TANAKA, Muneyuki MOTOYAMA, Ken-ichi ISHIMA and \\ Genzo HASHIZUME \\ (Industrial Research Institute of Hyogo Pref.)
}

\begin{abstract}
Smoking process of rooftiles has been reviewed and discussed relating to the problems in the manufacturing process. Three types of carbons were observed by SEM. One is the smooth plane carbon layered parallel to the basal plane which contributed to the luster of smoked tiles. The others were droplet-like and fibrous carbons which decreased the surface luster. It was found that smooth plane carbon layer was formed mainly by the direct decomposition of hydrocarbon in contact with the heated clay surface. Droplet-like and fibrous carbons were considered to be formed by partial decomposition of hydrocarbon in gas phase. Hence dilution of hydrocarbon by inert gas and lowering the decomposition temperature were useful for the prevention of the formation of droplet-like and fibrous carbons. Smoking propane at $900 \sim 950^{\circ} \mathrm{C}$ for $30 \sim 40 \mathrm{~min}$ after dilution by nitrogen to one-fouth and passage through water has given the best silver-luster tiles. The so called "rust" in the smoked tiles was also discussed.
\end{abstract}

[Received July 11, 1975]

\section{1. 緒言}

いぶし死は加熱された粘土素地に炭化水素を含むガス を接触させて素地表面に炭素を主成分とする炭素質膜 （以下単に炭素膜と称する）を形成した後, 炭素膜の燃 燒がないように普通は案を密閉して冷却する製造方法が とられる。

わが国で古くから用いられてきただるま嚜, 半倒焰窯 とよばれるいぶし死焼成窯では, 加熱室内の死素地が 800 ～ $1000^{\circ} \mathrm{C}$ となった際に，“こくぼ”と名付けられる 内容積の大きい燃焼室へ, 松材, 松葉, 石炭, 重油など の燃料を一度に投入して空気を断ち, 乾溜することで炭 化水素を生成させ，これを加熱室へ導く。この工程を燻 化，地方によって “こみ”，“くすべ”，“いぶし”などと よんでいる.欧米での smoking, blueing, Blaudämpfen
などの工程はすべて同様であるが，わが国で最近普及し

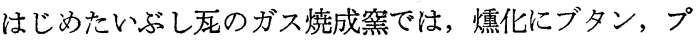
ロパンなど LPG の生ガスが使用されている.

このような工程で生ずる欠点として, 製品に容易に除 去し難い煤の付着, すなわち付着炭素といわれるもの， あるいはサビと称される茶褐色あるいは黒色の斑点や流 紋，さらに表面剝離などが往々にして発生しており，と くに LPG による燻化の場合に著しい：これらの久点の 発生を抑え，良好な銀色光沢を有するいぶし死が安定し て製造できる技術の確立は強く望まれるところである。 一方, 、ぶし死の燻化に関する研究で, 寺田 ${ }^{1)}$ は松材を 乾溜し， $400^{\circ} \mathrm{C}$ 以下での $\mathrm{CO}_{2}, \mathrm{CO}$ を主とするガス状溜 出分と, その温度以上での $\mathrm{CH}_{4}, \mathrm{C}_{m} \mathrm{H}_{n}$ の液状溜出分を 用い，粘土素地の鉄成分の還元状態挍よび煤状物質の発 
生などから，良好な銀色光沢を得るのに $\mathrm{CH}_{4}, \mathrm{C}_{m} \mathrm{H}_{n}$ に 対するこれらガス状溜出分と，水蒸気による稀釈効果に ついて言及している。

直接にいぶし虑を対象としたものではないが，熱分解 黒鉛に関する多くの研究報告の中から，、ぶし虑の燻化 を類推し得るものも少なくない，たとえば Hofmann ら 2) の約 $800^{\circ} \mathrm{C}$ での炭化水素の熱分解による磁器板上の Glanzkohlenstoff の生成実験の報告がある.これでは窒 素などの不活性ガスによる炭化水素の稀釈と，水蒸気の 導入は煤の発生を抑え, $\mathrm{C}+\mathrm{H}_{2} \mathrm{O}=\mathrm{CO}+\mathrm{H}_{2}$ で $\mathrm{C}$ を消費 さすこと, 炭酸ガスは $\mathrm{CO}_{2}+\mathrm{C}=2 \mathrm{CO}$ で水蒸気と同じ 効果のあることなど，寺田とほとんど同じ意見を示し た. その他, Diefendolf ${ }^{3)}$ による $1000^{\circ} \mathrm{C}$ 付近の炭化水 素の基板上の熱分解の研究でも, ガス濃度と煤の発生に ついて報告されている.

したがって今後のいぶし死の製造技術の研究には，前 述の欠点の発生の要因の解明と, 今迄の報告のごとき燻 化ガスの状態はもとより, 燻化の温度, 時間などの関倸 も明らかにされねばならないであろう。さらに Zimmer$\mathrm{mann}^{4)}$ のいう粘土素地の鉄分の量的な関係や, 石川ら ${ }^{5)}$ の炭素の黒鉛化に対するセリサイトの触媒効果の報告な ぞをみると，基板にあたる无素地の性状も燻化に関与す る重要な因子として考える必要がある.

また，いぶし虑の表面炭素膜については，現在までの 報告6) 8) では煌化条件に照らしての検討がなされてい ない憾があり，この解明も重要な課題と思われる.

以上のことから筆者らはいぶし虑に関して一連の研究 を実施した．本報では先ず付着炭素の生成条件と良好な 銀色光沢を有するいぶし死の燻化条件を見出すことを目 的として LPG による煄化に関して検討した結果を報告 する.

\section{2. 実 験 方 法}

\section{1 試料}

実験試料は淡路虐粘土の真空押出し成形素地，および その $1000^{\circ} \mathrm{C}$ 焼成体を用いた.この粘土の性状はすでに 報告9〉したので本報では省略する.

また，付着炭素，サビなど久点の検討試料として工場 から提供をうけたものは，同じ粘土素地で，燻化には $n$-ブタン, 鴯化開始温度は 900 950 $\mathrm{C}$ 圧力は 500 800 $\mathrm{mmAq}$ なかには，2000 mmAq に近いところむあり， 燻化時間は 30 分〜 1 時間のものである.

\section{2 燯化方法}

図 1 の（1）のごとき $\mathrm{SiC}$ 発熱体，内容積 $60 \phi \times 1000$ $\mathrm{mm}$ の䨒囲気炉を用い, $5^{\circ} \mathrm{C} / \mathrm{min}$ で昇温, 所定温度で窒 素ガスにより炉内を置換した後，鴯化ガスを $80 \mathrm{~m} l / \mathrm{min}$ で流した. 煄化ガスはプロパンガスおよび窒素で稀勫し たもので，その濃度はプロパンガスの分圧を変化させる

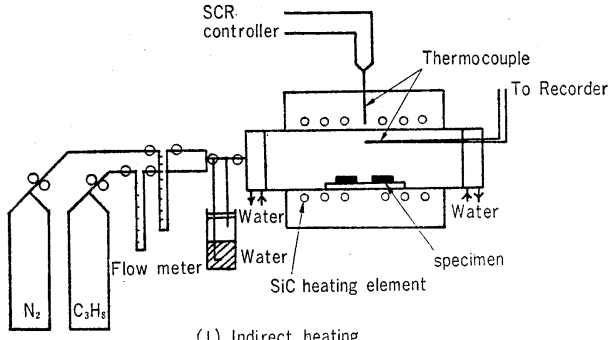

(1) Indirect heating

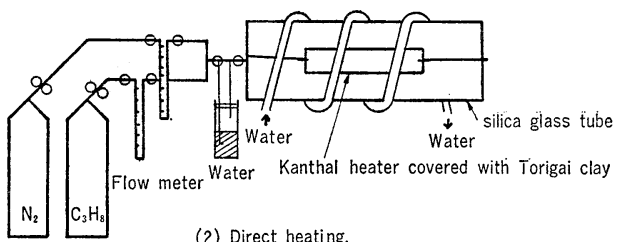

(2) Direct heating.

Fig. 1. The schematic diagrams of smoking apparatus.

ことで調節した．燻化で湿ガスとしたものは $500 \mathrm{ml}$ の 洗浄瓶の水中を通したものである.

図 1 の（2）の装置は，加熱素地に低温の燻化ガスを 接触した場合の検討に用いたもので，コイル状の発熱体 を素地に埋め込み石英ガラス管中で実験した．石英ガラ ス管を水冷したのは，石英ガラスが加熱され，その面に 付着する炭素により視野が妨げられるのを避けるためで ある.この場合の測温は光温度計によった.

\section{3 表面, 破面の検討方法}

X線回折および島津製，エレクトロンプローブマイク ロアナライザー（EMX-SM 型）を用いた.

表面光沢の測定には, 東洋理化製色差計により JIS Z 8722 の反射物体の測定法に準拠し, 刺激值 $Y \%$ をるっ て明度を比較した。

\section{3. 実験結果亡考察}

\section{1 製品に発生する付着炭素}

窒出しされた死が，一様に良好な銀色を呈しながら， 一部にその表面に刷毛でもっても除去し難い煤が付着す ることがある.これを付着炭素とよび，不完全然焼およ び炭化水素の熱分解から生じた梥内ガス中に浮遊する煤 と明らかに区別されるものである. 表面炭素膜および付 着炭素の粉末X 線回折図形は $\mathrm{HAF}^{*}$, EPC* などのカー ボンブラックと同様の回折パターンである. しかし図 2 の付着炭素赤査電子顕微鏡写真の (1) の破断面に見られ るように，炭素膜の上より繊維状にのびたものと，海綿 状の集合体があるが，この集合体をさらに高倍率で観察 した（2）では，すべて纎維状であることがわかる.

* High Abrasion Furnace, Easy Processing Channel の 略 


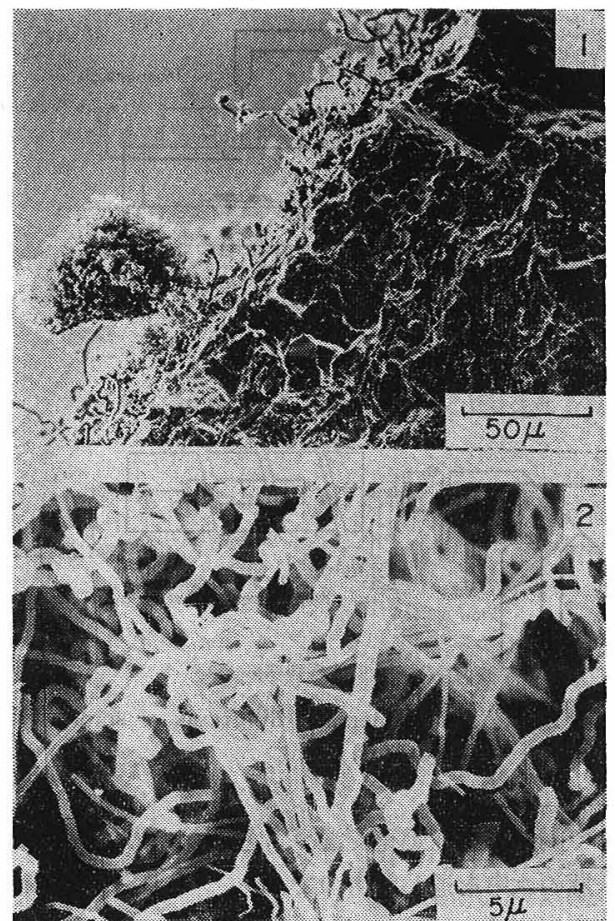

1. cross section of the specimen.

2. magnified image of fibrous carbon formed on the specimen surface.

Fig. 2. SEM of fibrous carbon.

\section{2 製品に登生する茶褐色および黒色の斑点}

窵出しした直後は一様に銀色を呈しているが，日時の 経過とともに茶褐色の斑点や流紋を生ずるものがある. とくに水と接触するとこの変化は速い.はなはだしいも のは素地を含めた剝離に発展するものもあり，豦業者は これを通常少ビとよんでいる.

また茶褐色には変化せずに，剝離の個所に黑色の集合 した粉体が存在する場合がある。この部分を調べると， 石英，長石の他に磁性を示す鉄化合物が検出された。一 般には別の欠点のように考えられているが，燻化条件と その前の加熱雾囲気により鉄化合物の状態が異ったと考 えられ，同様にサビに類するものである.

このよらにサビは素地中の鉄分の形態と分布が影響す る一方, 燻化によってうけた還元の状態により存在状態 が容易に左右されることで，この発生の防止には燻化ガ スの濃度, 時間などを適正に選ぶことが重要でめる。

これらの機構については別に報告する.

\section{3 生ガスによる燻化結果}

図1の（1）の装置を用いて，プロパンの生ガスによる 燻化結果を 表 1 に示す.このように生ガスの鴯化では, $800^{\circ} \mathrm{C}, 60$ 分，または $900^{\circ} \mathrm{C}, 30$ 分以内は良好であった が，燻化の温度が高くなるか，または燻化の時閒が長く なると，付着炭素が增加する傾向が認められた。

図 3 は 表 1 に対応する表面炭素膜の走查電子顕微鏡
写真である.これらより付着炭素は炭溸膜の上に油滴状 でまず付き，その油滴状ないしは球状の炭索汃連なり， しかも径をあまり大きく変化させずに緘維状に発達して

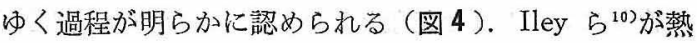
分解黑鉛で生成を述べたフィラメント状の煤も括艺らく この経過による同様のものと思われる.

Table 1. Effects of smoking condition on $Y$ value.

\begin{tabular}{|c|c|c|c|}
\hline $\begin{array}{l}\text { Smoking time (min) } \\
\text { Temperature }\left({ }^{\circ} \mathrm{C}\right) \\
\end{array}$ & 10 & 30 & 60 \\
\hline 800 & 12.1 & 13.8 & 15.2 \\
\hline 900 & 14.2 & 14.5 & $16.7^{*}$ \\
\hline 1000 & $12.2^{*}$ & $11.0^{* *}$ & $8.6 * * *$ \\
\hline
\end{tabular}

Number of symbol * indicates degree of generation of dropletlike and fibrous carbon.

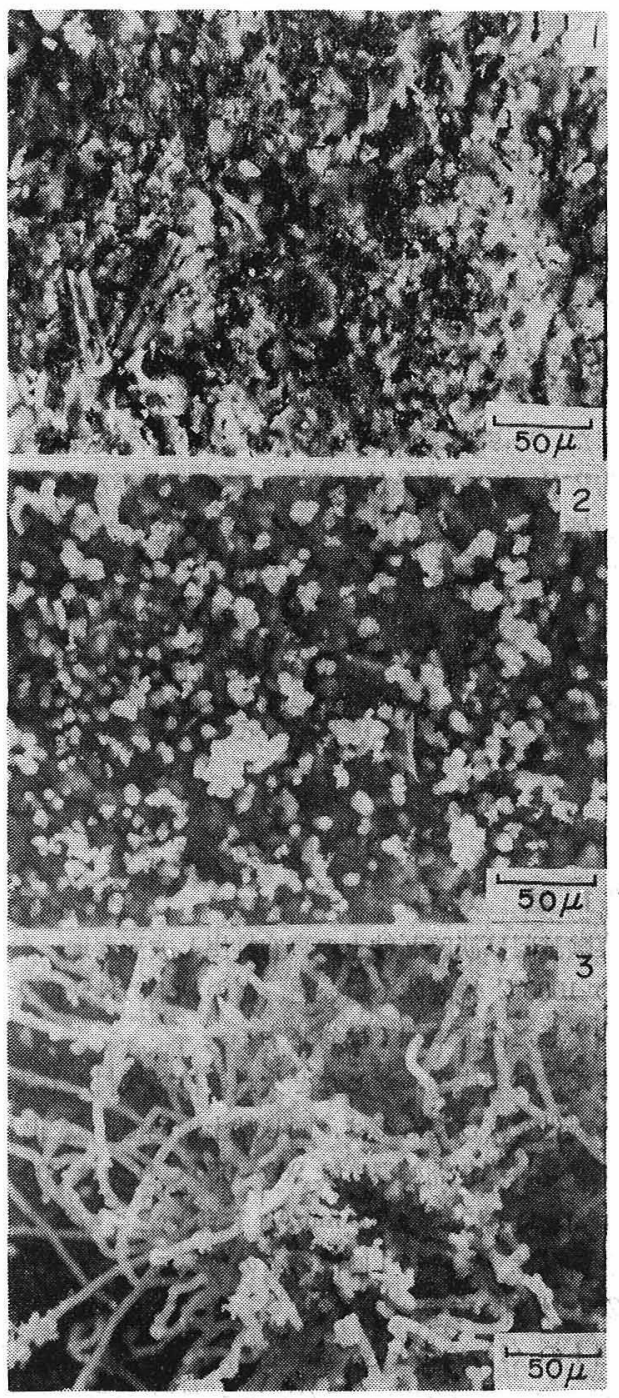

(1) smoked for $10 \mathrm{~min}$.

(2) smoked for 30min.

(3) smoked for $60 \mathrm{~min}$.

Fig. 3. SEM of the surface of specimen smoked at $1000^{\circ} \mathrm{C}$ 


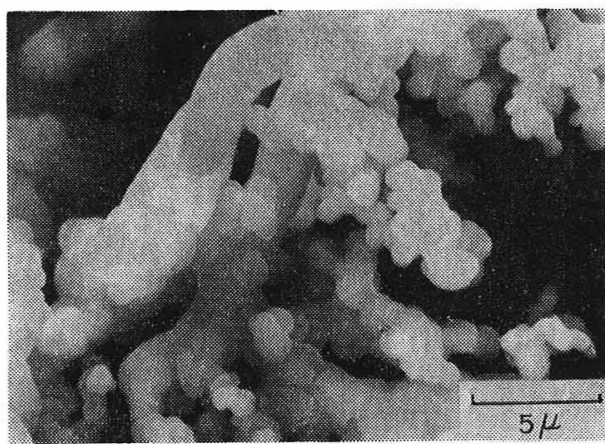

Fig. 4. SEM of fibrous carbon formation. Droplet carbons are bound together to form a fibrous carbon.

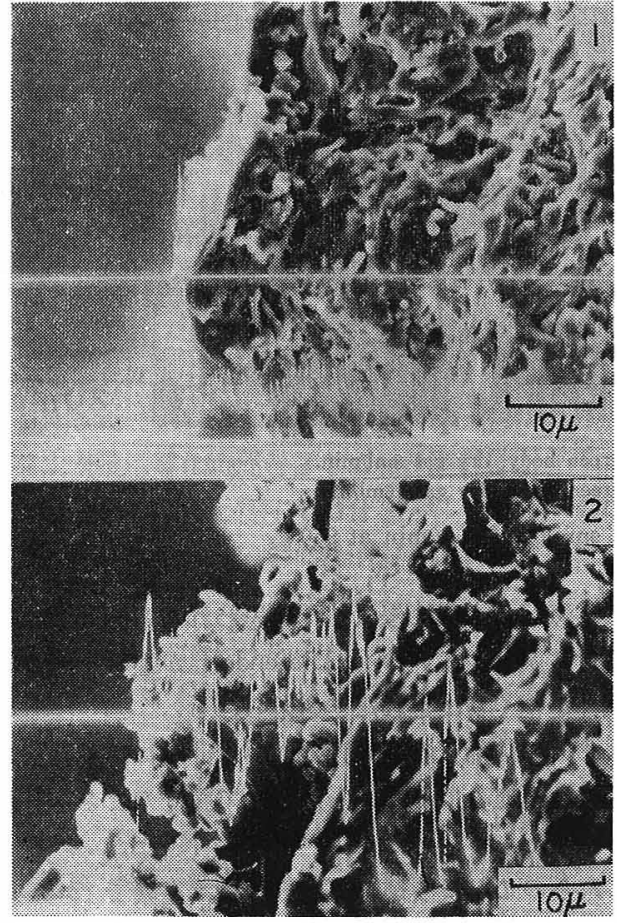

(1) smoked for $10 \mathrm{~min}$.

(2) smoked for 60min.

Fig. 5. SEM of the fracture surface of specimen smoked at $1000^{\circ} \mathrm{C}$

図 5 は破断面の走査電子顕微鏡写真と, 炭素の線分析 の結果である. 炴化時閒 10 分のものは, 表1のとおり 、ぶし死の銀色としては上の製品の部に入るものである が，線分析の結果と照らして炭素膜の厚みは約 $1 \mu$ 程 度であるが，60 分燻化したものは，炭素膜は約 $10 \mu$ 程 度の厚みを有し，かつ粘土素地の気孔へ根を下したごと く炭素が浸透しているのが認められる．60分燻化のもの が銀色光沢が劣るのは，前述の付着炭素がその原因と考 えられる.このよらに炭素膜は燻化時間とともにその厚 みを增すことが明らかとなった。これら傍熱型の炉を用 い，試料基体とともに燻化ガスの温度も上昇する場合に
はさらに長時間燻化を行っても炭素膜としての厚みは約 $10 \mu$ が限度で付着炭素が増加するのみであり，Y值はさ らに低下する結果となった，ちなみに市販の一級品のい ぶし虑の炭素膜を調べると，ほとんど $10 \mu$ 程度の厚み である。

\section{4 燯化ガスの稀釈效果}

前述したように寺田は松材を乾溜したとき生成するガ スを調べるとメタンをはじめとする種々の炭化水素の他 に $400^{\circ} \mathrm{C}$ 以上でも多くの水素, 一酸化炭素および炭酸 ガスが含まれていることを報告している．また燻化ガス の温度は時間とともに変化するが，一定となるにはかな りの時間を要する ${ }^{11}$ 。この結果やまたはじめに述べた多 くの研究者の意見を総合しても, 現在ガス致で行われて いる LPG の生ガス，すなわちプロパンあるいはブタン を 100\% 近い濃度で燻化ガスとして用いることに検討を 要するのは自ずと明らかである．これを稀釈するには工 業的には窒素，崖酸ガスなどが考えられるが，本実験で は窒素を用いた。

表 2 ではプロパンに対する窒素が $1: 1$ 以上で付着炭 素の発生は全くなく，この場合の $Y$ 值も表 1 の稀釈の 無い場合より，すべて高く，銀色光沢度は増加した.と

Table 2. Effects of dilution by nitrogen on $Y$ value.

(Smoked for $30 \mathrm{~min}$ at $1000^{\circ} \mathrm{C}$ )

\begin{tabular}{cccc}
\hline $\mathrm{C}_{8} \mathrm{H}_{8}$ & $:$ & $\mathrm{N}_{2}$ & $Y(\%)$ \\
100 & $:$ & 0 & $11.0^{* *}$ \\
50 & $:$ & 50 & 17.5 \\
25 & $:$ & 75 & 20.0 \\
25 & $:$ & 75 (wet gas) & 22.0 \\
\hline
\end{tabular}

Number of symbol * indicates degree of generation of dropletlike and fibrous carbon.

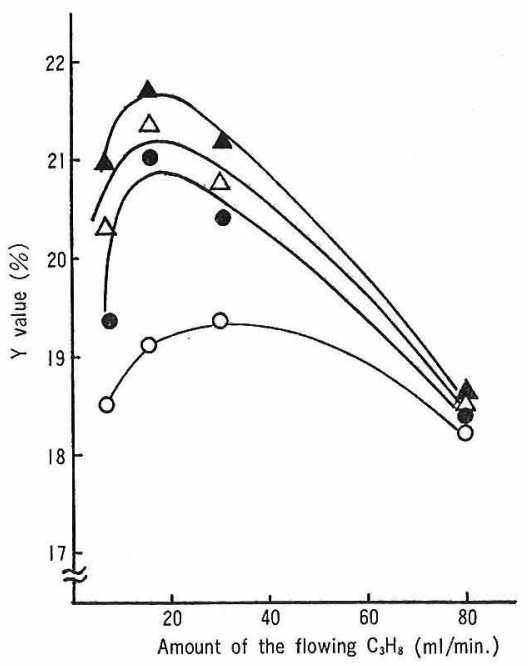

$\Delta$ green body wet gas, $\Delta$ green body dry gas

- fired body wet gas, $O$ fired body dry gas

Fig. 6. Effects of bodies and water vapor on the $Y$ value of specimen surface smoked for 30 min at $950^{\circ} \mathrm{C}$. 


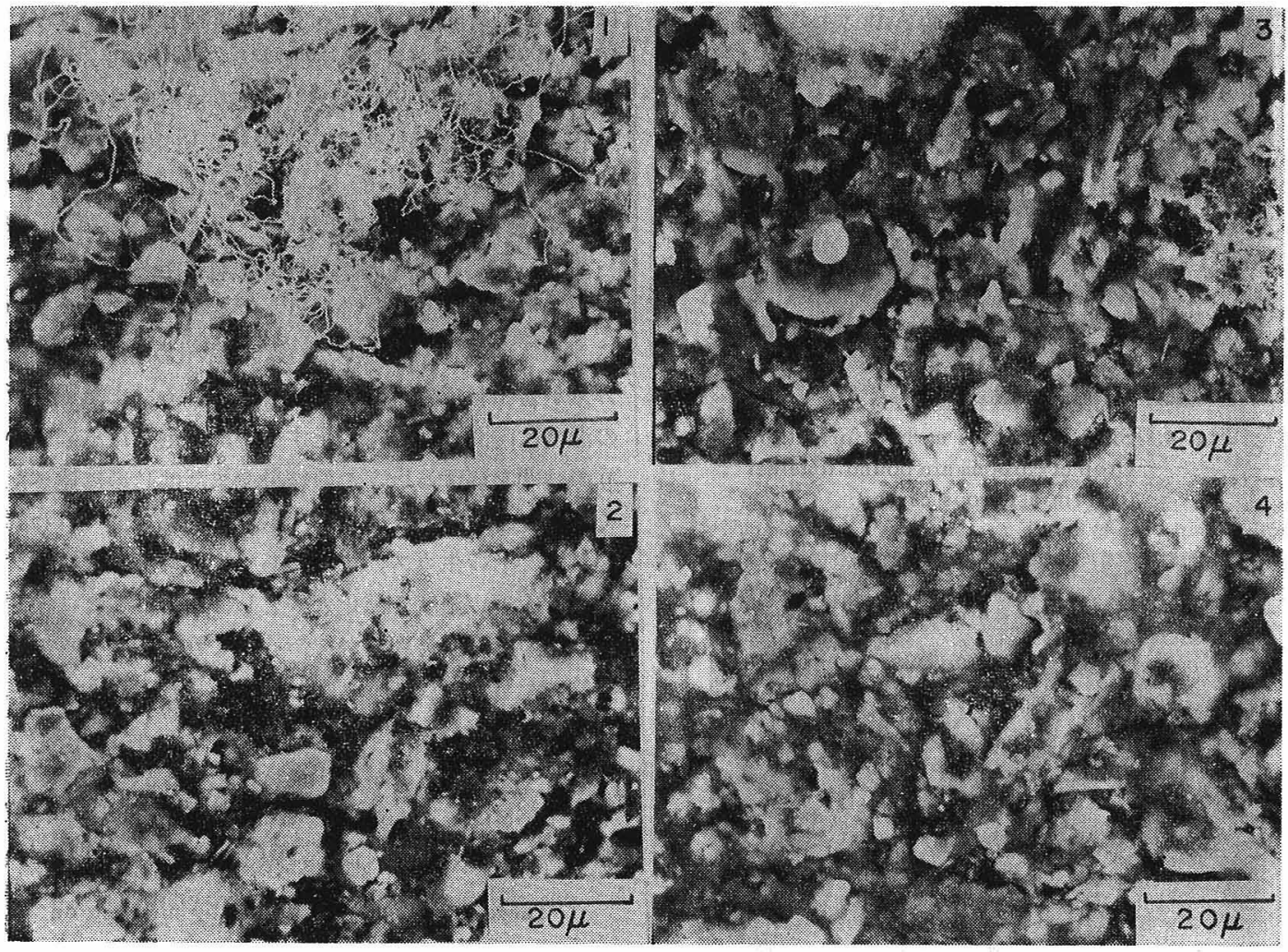

(1) green body, wet gas $8 \mathrm{ml} / \mathrm{min}$. (2) green body, wet gas $16 \mathrm{ml} / \mathrm{min}$.

(3) green body, dry gas $8 \mathrm{ml} / \mathrm{min}$.

(4) green body, dry gas $16 \mathrm{ml} / \mathrm{min}$.

Fig. 7. SEM of the surface of specimen smoked for $30 \mathrm{~min}$ at $950^{\circ} \mathrm{C}$.

くに $1: 3$ 程度の稀釈が有效なことを示しており，これ を水中を通して湿ガスとして用いたものは最も高い光沢 度を示した。

図 $\mathbf{6}$ は $950^{\circ} \mathrm{C}, 30$ 分の燻化で生素地を加熱して燻化し た場合と, 素地が $1000^{\circ} \mathrm{C}$ に予め焼成されたものの燻化 を比較したものである.表 2 の実験結果と同じく $2 \sim 4$ 倍の稀釈と燻化ガスを湿ガスとした場合の効果は明らか であるが，焼成素地の燻化が生素地加熱のそれより光沢 度が低下寸ることが認められた. 事実, 虑業者は二度焼 （燻化の不良品の再焼成）の虑生素地からのものより 悪いといらし，また㘹結をよくするため燻化温度より高 く焼き，その後，温度を下げてから燻化するのは銀色が 良くないともいう. 図6 はそれを裹付けるような結果で あるが，その原因は表面の活性によるものとも思われ， 今後の研究で明らかにしたいと考えている.

Diefendolf ${ }^{3)}$ は低濃度のガスは㖼の発生はないとしな がらも，750 $1000^{\circ} \mathrm{C}$ の低温では熱分解ガス中の $10 \sim$ $100 \mathrm{ppm}$ の微量の酸素はウイスカーの形成をもたらすと 述べている，事実，篻者らの実験で，10倍稀釈でこのよ うな条件，すなわち炭化水素に対する窒素の割合の増加 で窒素中の微量の酸素により図 7 のごとく生成したと思 われる付着炭素を認めたこともある. 工場においても空
内に空気がわずかに侵入したと思われる㥶詰場所に㵶維 状の付着炭素が多いのも Diefendolf が述べているよう な条件がつくり出されたと考えられる。

なお，10倍稀勫の炭素膜の厚みは非常に薄く, 炭素膜 の形成も不充分であり，乙たがって図 6 のごときY值の 低下をもたらす。

これらのことより燻化ガスの稀釈は穻素で行ら場 合 $3 \sim 4$ 倍が適当と考えられる.

\section{5 加熱素地に低温の燻化ガスを接触させた場合}

図 1 の（2）の装置を用い，素地中に埋め込まれた発鴊

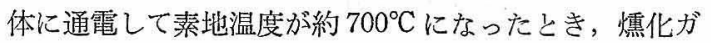
ス（プロパン生ガスで $80 \mathrm{ml} / \mathrm{min}$ の流量）を送大する と，瞬時に炭素膜が形成されることが石英ガラス管外よ り観察された. 素地温度を約 $1000^{\circ} \mathrm{C}$ に保ら, 60分閒燻 化ガスと接触させた場合も, 表 1 に示しそ実験結果と異 没り，炭素膜は $Y$ 值約 $20 \%$ の良好な銀色光沢を呈し, 付着炭素は認められなかった。

䈉者らはいぶし虐の良好な銀色光沢を有する炭素膜を X線スペクトルと高分解能電子顕微鏡写真などで調べた 結果，素地面に平行な結晶子の配向を報告した ${ }^{12)}$. しか し加熱素地に低温の炭化水素が触れるとほとんど同㭙に 炭素膜の形成が認められた本実験の結果から，矢島の報 
告するような気相に黒鉛結晶核を生じこれが基体上に沈 着するといら過程 ${ }^{13}$ が，死素地とガスとの接触面上のご く限られた範囲では生じているかも知れない。

Diefendolf $^{3)}$ の炭化水素が高濃度, かつ高温で気相分 解するときのみ煤の発生を伴う, との報告と 3.3 での傍 熱型の結果と合わせて考えると, いぶし虏の表面炭素膜 に関しては, 従来考えられていた炭化水素の気相分解に より生じた炭素が素地に沈着するといらより, むしろ素 地との接触による分解で炭素膜を形成すると考えた方 が,形成過程を表わすのにより適切であると考えられる.

\section{4. 総 括}

いぶし死製造において発生するトラブルのうち, 付着 炭素, サビに注意し，LPG を用いる場合の燻化条件を 検討した．本実験に用いた試料の結果から次のことが明 らかになった。

付着炭素は炭素膜上に最初油滴状に付き，それが連な って繊維状に発達する．これは燻化の温度が高いか，あ るいは時間が長いと付着が多くなることがわかった。

サビは炭素膜に近い素地中の鉄成分が燻化によって還 元され，その後の酸化によって生ずるが，黒色のものは 磁性をおび, 素地中の鉄分の形態と分布, 燻化の条件の 影響が大きい。

表面炭素膜は燻化時間とともにその厚みを増すが，図 1 の実験装置で燻化を行った場合には, 最大で約 $10 \mu$ であり，それ以上の長い燻化では付着炭素の増加が示さ
れた。

本実験において，良好な銀色光沢を有するいぶし虑の 燻化の条件は, 温度 $900 \sim 950^{\circ} \mathrm{C}$, 燻化時間 $30 \sim 40$ 分間 位で，燻化ガスにプロパンを用いる場合， $3 \sim 4$ 倍に窒 素で稀釈し，水中を通して湿ガスとしたのが最適であっ た. また雳化温度よりも高い温度に焼成された場合は, 銀色光沢は苾くなる傾向を示した.

表面炭素膜は, 従来考えられていた炭化水素の気相分 解によって生じた炭素が素地に沈着するというより，炭 化水素と素地との接触による分解で炭素膜を形成すると した方が適切と考えられる。

\section{文献}

1）寺田 清, 窒協 59 377-82 (1960).

2) U. Hofmann, K.A. Hofmann, Ber. Deut. Keram. Ges. 10, 157-69 (1926).

3) R.J. Diefendolf, J. Chem. Phys. 57, 815-21 (1960),

4) K. Zimmermann, Ber. Deut. Keram. Ges. 18, 110-20 (1937).

5）石川忠夫, 吉沢四郎, 工化 66, 929-33 (1963).

6） 丸山宰治, 寺田 清, 若松 盈, 窯協 62, 611-13 (1954).

7）馬場政幸, 川久保正一郎, 日化. 5, 886-92 (1972).

8）大谷朝男, 花岡紘一, 大谷杉郎, 炭素材料学会第 1 回年 会要旨集 (1974).

9) 田中 稔, 隅田 卓, 窯協, 81 [9] 369-78 (1973).

10) R. Iley, H.L. Riley, J. Chem. Soc. 1362 (1948).

11）寺田 清, 倒焰式加熱窟の理論と実際 p. 147 日本出版 印刷社 (1956).

12）元山宗之, 石間健市, 橋詰源蔵, 田中 稔, 窒協 1975 年 年会要旨集 B32 p. 115 (1975).

13）矢島聖使，セラミックス 4 [4] 296-300 (1969).

(7/11/1975 受付)

\title{
論文・Paper
}

\section{クリソタイルの配向性の $\mathbf{X}$ 線回折法による研究}

\author{
音 馬 峻* • 宇田川重和** • 浦 部 和 順** • 矢野豊 彦**。竹 滋 雄* \\ (*日本フスベスト(株), **東京工業大学 工学部 無機材料工学科)
}

\section{$\mathbf{X}$-ray Studies on the Orientation of Chrysotile in the Asbestos Products}

\author{
By \\ Takeshi OTOUMA*, Shigekazu UDAGAWA**, Kazuyori URABE**, \\ Toyohiko YANO** and Shigeo TAKE* \\ (* Research Laboratory, Nippon Asbestos Co., Ltd. \\ ** Department of Ceramics Engeneering, Tokyo Institute of Technology
}

The orientation of chrysotile in the asbestos products was studied by $\mathrm{X}$-ray diffraction method. The $\mathrm{X}$-ray diffraction profiles from the chrysotile with various degree of orientation were theoretically calculated using a probability function and the diffraction profiles from a 